ЯМЕЛЬСЬКА

Христина Юрї̈вна yamelska.k@gmail.com



аспірантка, Інститут міжнародних відносин Київького національного університету імені Тараса Шевченка, адвокат, керівник Адвокатського бюро "Ямельської Христини"
УДК 341.1/8

\begin{abstract}
ЮРИДИЧНИЙ ЗМІСТ ПОНЯТЬ "КАТУВАННЯ", "НЕЛЮДСЬКЕ ПОВОДЖЕННЯ АБО ПОКАРАННЯ", "ПОВОДЖЕННЯ АБО ПОКАРАННЯ, ЩО ПРИНИЖУС ЛЮДСЬКУ ГІДНІСТЬ" ТА ЇХ РОЗМЕЖУВАННЯ У РІШЕННЯХ ЄВРОПЕЙСЬКОЇ КОМІСІЇ 3 ПРАВ ЛЮДИНИ ТА ЄВРОПЕЙСЬКОГО СУДУ $З$ ПРАВ ЛЮДИНИ
\end{abstract}

\section{THE LEGAL MEANING OF THE TERMS "TORTURE", "INHUMAN TREATMENT OR PUNISHMENT", "DEGRADING TREATMENT OR PUNISHMENT" AND THEIR DISTINCTION IN THE DECISIONS OF THE EUROPEAN COMMISSION OF HUMAN RIGHTS AND THE EUROPEAN COURT OF HUMAN RIGHTS}

YAMELSKA Khrystyna - postgraduate student, Institute of International Relations of Taras Shevchenko National University of Kyiv, Lawyer, Head of "Yamelska Khrystyna Law office"

У статті розкрито юридичний зміст понять «катування», «нелюдське поводження або покарання», «поводження або покарання, щзо принижує людську гідність». Досліджено генезу виникнення вищевказаних понять через призму рішень Свропейської комісії з прав людини та Свропейського суду з прав людини. Проведено розмежування між даними поняттями на прикладах судових рішень європейських судових органів. У статті розкрито абсолютний характер норми јиз сояепs ст. 3 Конвениії з прав людини та основоположних свобод. Автор пропонує модернізувати українське кримінальне законодавство з проведення рецепції позичії Свропейського суду з прав людини із розмежування вказаних понять.

$* * *$

The paper reveals the legal meaning of the terms "torture", "inhuman treatment or punishment", "treatment or punishment that degrades human dignity". A distinction between these concepts is made on the examples of court decisions of European courts, taking into account the individual circumstances of each case. The genesis of the origin of the above concepts is investigated through a prism of the decisions of the European Commission of Human Rights and the European Court of Human Rights.

The paper reveals the absolute nature of the "jus cogens" norm of Article 3 of the Convention for the Protection of Human Rights and Fundamental Freedoms. The author proposes to modernize the Ukrainian criminal legislation on the reception of the position of the European Court of Human Rights on the delimitation of these concepts.

In contrast to the European convention regulation of ill-treatment, torture, inhuman or degrading treatment or punishment, the author notes that the Ukrainian legislation regulates this issue quite succinctly. The Article 127 of the Criminal Code of Ukraine provides a definition only of torture, which in essence coincides with the definition of the United Nations Convention against Torture and Other Cruel, Inhuman or Degrading Treatment or Punishment and the position of the European Court of Human Rights.

The paper notes that the practice of Ukrainian courts shows that a distinction (similar to that provided by the European Court of Human Rights) is not implemented.

Ключові слова: катування, нелюдське поводження або покарання, поводження або покарання, щяо принижує людську гідність, Європейська комісія з прав людини, Європейський суд з прав людини

Keywords: torture, inhuman treatment or punishment, degrading treatment or punishment, the European Commission of Human Rights, the European Court of Human Rights

\section{ВСТУП}

Сьогодні велике праксіологічне значення має забезпечення захисту фундаментальних прав і людини від свавільного втручання з боку публічної влади та порушення іншими особами. Це знаходить своє відтворення у конструкції постмодерного міжнародного механізму захисту прав людини у вигляді запровадження спеціальної правової охорони та покладення зобов'язань на держав учасниць відповідних міжнародних обов'язків із недопущення та протидії таких посягань. 3 праксіологічного погляду ключове значення тут має питання міжнародно-правового визначення понять «катування», «нелюдського поводження або покарання», «поводження або покарання, що принижує людську гідність» і відповідно їх заборону.

\section{Аналіз останніх досліджень та публікацій}

Тематику катування, нелюдського поводження або покарання, поводження або покарання, що принижує людську гідність досліджували Ч. Беккарія, М.М. Гнатовський, В.О. Човган, Е. В. Шишкіна, А.Ю. Замула, Д.Г. Михайленко, А. В. Савченко, Ю. Кричун, Дж. Мирдоч, С.А. Разумов, Ю.Ю Берестньов та ін.

META статті - розкрити юридичний зміст понять «катування», «нелюдське поводження або покарання», «поводження або покарання, що принижує людську гідність», дослідити виникнення вищевказаних понять через призму рішень Свропейської комісії з прав людини (далі - ЄКПЛ) та Європейського суду з прав людини (далі - ССПЛ); провести розмежування між даними поняттями на прикладах судових рішень європейських судових органів. 


\section{ВИКЛАД ОСНОВНОГО МАТЕРІАЛУ}

Відповідно до ст. 1 Конвенції про захист прав людини і основоположних свобод (далі Конвенція) Високі Договірні Сторони гарантують кожному, хто перебуває під їхньюю юрисдикцією, права і свободи, визначені у розділі I цієї Конвенції, зокрема гарантують заборону катування (Нікого не може бути піддано катуванню або нелюдському чи такому, щзо принижує гідність, поводженню або покаранню) [1].

Це положення Конвенції є відтворення концепту людиноцентристської правової ідеології та закріплює ключовий для демократичного світу принцип недопущення катувань, що $є$ обов'язковим для відтворення у національних правових систем держав-учасниць.

Доцільно ст. 3 Конвенції розглядати у системному взаємозв'язку зі ст. 15 Конвенції, де йдеться про те, що за жодним 3 положень ст. 3 не може бути зроблено відступ від зобов'язань. Тобто встановлена Конвенцією заборона має абсолютний характер.

Ст. 3 Конвенції не надає характеристик, що визначають поняття «катування», «жорстоке поводження або покарання», «нелюдське поводження або покарання», «поводження або покарання, що принижує людську гідність». Навпаки, вона є досить лаконічною у порівнянні, наприклад, зі ст. 8 Конвенції.

Визначення критеріїв розмежування цих понять розроблені у ході розвитку судової практики ЄСПЛ та ЄКПЛ у рамках системи інституцій Ради Європи.

Далеко не кожен акт неналежного поводження підлягає регулюванню ст. 3 Конвенції. Аналізуючи практику ЄСПЛ у справах, у котрих містяться порушення ст. 3 Конвенції, можна констатувати, що суд опирається у кожному конкретному випадку на наявність «мінімального ступеню жсорстокості» у цих правопорушеннях.

Варто зазначити, що ЄСПЛ неодноразово підкреслює відносний характер оцінки «мінімального ступеня жорстокості», що залежить від комплексу обставин кожної конкретної справи. Доволі часто є проблемним визначення рівня достатньої жорсткості та відповідності його ст. 3 Конвенції.

Тільки після запевнення у тому, що поводження із потерпілою особою у кожній конкретній скарзі переступає «мінімальний ступінь жорстокості», ССПЛ та СКПЛ приймають рішення про проведення розмежування між «катуванням», «жорстоким поводженням або покаранням», «нелюдським поводженням або покаранням», «поводження або покаранням, що принижує людську гідність».

У визначенні «мінімального ступеня жорстокості» враховується тривалість такого поводження, фізичні та психічні наслідки такого поводження, стать, вік і стан здоров'я потерпілої особи. Крім того, критерії допустимого рівня жорстокості залежать від країни, де вчинювалось дані правопорушення, соціальних груп та їх відношення до різного рівня неналежного поводження стосовно себе та інших осіб, релігійних, культурних усталень, культурного рівня індивіда. Фактично має певною мірою місце врахування особливостей національних правових систем.

Однак, не дивлячись на всеохоплюючу юрисдикцію Конвенції та іiі вплив на різноманітні соціальні групи, на сьогодні спостерігається тенденція до уні- фікації певних критеріїв визначення «мінімального ступеня ж⿻рстокості», розроблення стандартів поводження у пенітенціарній сфері, розширення дії ст. 3 Конвенції.

Великою мірою визначення понять та їх критеріїв розмежування проходить через призму судових прецедентів ЄСПЛ. У рішеннях ЄСПЛ, зокрема, у справі Греції 1969 р. та справі Ірландії проти Великої Британії 1978 р. визначено деякі критерії визначення вищезазначених понять.

У ході справи Греції 1969 р., котра, до слова, було першою справою, де розглядалось порушення ст. 3, ЄКПЛ розглядала дії воєнної хунти після військового перевороту 1967 р. та визначила основний підхід до розмежування трьох заборонених дій - «катування», «нелюдського» і «такого, що принижує гідність» поводження чи покарання. [2]

Різний ступінь жорстокості був розглянутий ЄКПЛ у справі «Ірландії проти Великої Британії» (1977) [3]. На ньому розглядалася поводження військ Великої Британії з особами, підозрюваними у співпраці з Ірландською Республіканською Армією, і що мало місце у Північній Ірландії. Справа була порушена урядом Ірландії, що звинувачував Велику Британію, inter alia, у тому, що методи ведення допиту 3 використанням «п'яти технічних прийомів» - позбавлення сну, стресова обстановка, позбавлення їжі і пиття, схильних до шуму і надягання на голову каптура - $є$ порушенням ст. 3 Конвенції.

Хоча вказаний підхід до розмежування цих правопорушень у подальшому зазнав певних змін, він залишився стандартом для європейських судових органів. Катування виокремлено як особлива форма жорстокого поводження, що завдає людині найглибших травм.

\section{"Катування"}

ССПЛ у визначенні поняття катування посилається на ст. 1 Резолюції 3452, прийнятої Генеральною Асамблеєю ООН 9 грудня 1975 р. в якій йдеться: «катування являє собою посилений та умисний вид жорсткого, нелюдського чи принижуючого гідність поводження і покарання» [4].

ЄСПЛ ніколи самостійно не надавав визначення поняття катування, натомість у прийнятті рішень часто звертався до визначення, що міститься у Конвенції ООН проти катувань, яка вступила в силу 26 червня 1987 р. Такий підхід видається правильним 3 огляду на потребу у захисті фундаментальних прав людини і відповідно $є$ спрямованою на певну уніфікацію підходів до заборони катувань.

У ст. 1 Конвенції ООН проти катувань надається наступне визначення:

«термін "катування" означає будь-яку дію, якою будь-якій особі навмисне заподіюються сильний біль або страждання, фізичне чи моральне, щзоб отримати від неї або від третьої особи відомості чи визнання, покарати ї̈ за дї, які вчинила вона або третя особа чи у вчиненні яких вона підозрюється, а також залякати чи примусити ї̈ або третю особу, чи з будьякої причини, щуо трунтується на дискримінації будьякого виду, коли такий біль або страждання заподіюються державними посадовими особами чи іниими особами, які виступають як офіиійні, чи з їх 
підбурювання, чи з їх відома, чи за їх мовчазної згоди. В иеей термін не включаються біль або страждання, щзо виникли внаслідок лише законних санкцій, невіддільні від ичих санкиій чи спричиняються ними випадково» [5].

Тобто у визначенні катування у розумінні Конвенції ООН проти катувань можна визначити наступні характерні елементи:

- умисність вчинюваного діяння,

- спричинення сильного болю або страждання фізичного чи морального характеру,

- мета вчинюваного діяння, отримання відомостей, покарання, залякування.

Фактично, виділені характерні елементи визначення катування є тими критеріями, котрі суд виділяє у кожній конкретній справі, надаючи правопорушенню юридичну кваліфікацію катування в межах ст. 3 Конвенції. Ці критерії проходять червоною ниткою від перших справ 1979 р. та справ сьогоднішнього дня. Це дає усі правові підходи стверджувати про формування цілісного концепту розуміння елементів змісту поняття катування в практиці суду.

Слід зазначити, що ЄСПЛ утримався від складання списку дій, які автоматично повинні вважатися досить жорстокими, щоб бути класифіковані як катування. Суд завжди залишав за собою певну свободу у класифікації заборонених дій, заявляючи, що Конвенція «є живим документом, який слід трактувати в світлі сучасних умов» [6]. Такий підхід варто вважати цілком правильним, бо він дозволяє Суду завжди враховувати фактичні обставини кожної конкретної справи у визначенні відповідності іiі обставин змісту поняття катування.

У ході розгляду Грецької справи ЄКПЛ постановила, що відмінною рисою катування $є$ не характер і ступінь жорстокості вчиненого діяння, але переслідувана нею мета:

«Будь-яке катування є нелюдським і принижуючим гідність видом поводження, а нелюдське поводження завжди принижує гідність. Поняття нелюдського поводження має на увазі такий вид поводження, яким умисно заподіюється сильне страждання, психічного або фізичного характеру, $і$ яке в даному випадку не може бути виправдано ... Тортури застосовується з метою отримання відомостей або змусити визнання, або в якості покарання, $i$, як правило, являє собою посиленою формою нелюдського поводження. Вид поводження чи покарання, щуо застосовується до будьякої особи вважається таким, щуо принижує його гідність у тому випадку, якщо воно принижує його гідність в очах інших осіб, або спонукає його до вчинення дій проти його волі або совісті» [2].

Тобто у даному випадку ЄКПЛ у кваліфікації діяння як катування, опирається на критерій мети вчинюваного діяння, про який зазначається у ст. 1 Конвенції ООН проти катувань.

Варто відзначити, що розглядаючи запропоновану Конвенцією дефініцію поняття катування $з$ позиції теорії кримінального права варто вести мову про прямий умисел як форму вини.

Першим рішенням ЄСПЛ у справі про катування стосовно однієї особи було рішення у справі «Аксой проти Туреччини» (1996) [7]. Суд постановив, що для вчинених правопорушень потрібен був умисел, відповідні підготовка та зусилля для реалізації задуманого. Катування було застосовано з метою отримання зізнань або інформації від заявника.

Тобто у даній справі ЄСПЛ у кваліфікації вчиненого правопорушення апелює до критерію мети вчинюваного діяння, а саме отримання відомостей. Такий підхід Суду кореспондує з підходом національного законодавця в ряді країн Континентальної Свропи.

У справі "Салман проти Туреччини» (2000) [8] ЄСПЛ відзначив про умисність вчинюваних діянь стосовно заявника, а також присутністю елементу мети, наприклад, примушування до давання свідчень, як це визначено в Конвенції ООН проти катувань. Крім того, Суд постановив, що заявник піддавався дуже серйозним стражданням, які прирівнюються до катування, виходячи з характеру $і$ ступеня жорстокості поводження і фактів вказують на те, що страждання заподіювалися під час допиту та для отримання певних свідчень.

У рішенні у справі «Дікме проти Туреччини суд» (2000) [9] констатував катування із метою отримання зізнання та відомостей. Аналогічно у схожих справах, де потерпілим $є$ затримана особа та знаходиться під вартою чи у тюремній установі, суд часто приходить до висновку, що катування вчиняються із метою отримання певних відомостей та інформації.

Отже, критерій навмисності і цілеспрямованості поводження є дуже важливим при кваліфікації правопорушення судом у контексті катування.

У вищезгаданій справі «Ірландії проти Великої Британії» (1977) [3] СКПЛ дійшла висновку про наявність фактів катування та жорстокого поводження та наявність порушення ст. 3 Конвенції.

Однак після того як ЄСПЛ переконався, що був досягнутий мінімальний ступінь жорстокості, і справа може бути розглянута у контексті порушення ст. 3, перейшовши до питання про розмежування понять катування, нелюдського та такого, що принижує гідність поводження, не погодився із висновками СКПЛ.

Відповідно ЄСПЛ постановив, що катування повинне класифікуватися як вид поводження, який приносить найбільш серйозні і глибокі страждання. Так, він дійшов висновку, що визначальний критерій у класифікації дії як катування є ідентичним визначенню критерію мінімального порогу жорстокості, необхідному ст. 3, тобто є суб'єктивним рішенням, заснованим на визначенні ступеня болю і страждання, викликаними даними діями.

Як і ЄКПЛ, так і ЄСПЛ визначили п'ять методів ведення допиту, застосовуваних військами Великої Британії як нелюдське поводження. Однак, на відміну від позиції комісії, на думку ССПЛ, «ступінь страждань і жорстокості» застосовуваних методів "не відповідає ступеню страждань і жорстокості, які маються на увазі у визначенні «катування»" [3].

Отже, таке рішення суду створило прецедент для розмежування між тортурами, нелюдським і принижуючим гідність видом поводження чи покарання, на підставі, пери за все, ступеня жсорстокості, а не цілі їх застосування.

Порогом жорстокості Суд і Комісія користувалися і у прийнятті подальших рішень. Знаковою справою, 
у котрій ЄСПЛ керувався критерієм жорстокості, є справа «Айдин проти Туреччини» (1997) [10]. Суд знову підтвердив визначення катування, прийняте в справі Ірландії проти Великої Британії, і постановив, що за певних обставин під час згвалтування жертві можуть бути нанесені фізичні та моральні травми, ступінь жорстокості яких дорівнює ступеню жорстокості катування. Розглядалася справа 17-річної дівчини, затриманої турецькою поліцією за підозрою у приналежності до Партії Робітників Курдистану. Відповідно до обставин справи під час ув'язнення іiі роздягли, побили, облили холодною водою під сильним напором, зав'язали очі і згвалтували.

ССПЛ постановив: «Згвалтування вчинене представником влади має розглядатися як особливо тяжка i огидна форма жорстокого поводження, яка дає можливість злочинцю скористатися вразливістю і слабкою опірністю потерпілого. До того ж згвалтування залишає глибокі довготривалі психічні наслідки, які перевершують наслідки інших фізичних і психологічних форм насильства ... взявши до уваги всі обставини, Суд визнав, що сукупність дій, що мали характер фізичного і психологічного насильства, ... і особливо акт жорстокого згвалтування, якому була піддана жертва, $\epsilon$ порушенням ст. 3 Конвенції, і рівносильні катуванню» [10].

Так, Суд постановив, що страждання, викликані згвалтуванням та іншими актами жорстокого поводження, відповідають порогу жорстокості катування і повинні бути класифіковані як таке.

Як вже зазначалося вище, ЄКПЛ та ЄСПЛ утрималися від складання списку дій, які автоматично повинні вважатися достатньо жорстокими, щоб класифікуватися як катування. Суд завжди залишав за собою певну свободу у класифікації заборонених дій і досить завбачливо було з його боку заявити, що Конвенція «є живим документом, який слід трактувати у світлі сучасних умов» [6].

Це положення отримало рішуче підтвердження у справі «Сельмуні проти Франції» (1999) [11]. У даному випадку висувалися звинувачення у жорстокому поводженні різної форми під час тримання заявника під вартою у поліції під вартою, а саме: у постійних побиттях кулаками, важкими предметами.

Прийнявши до уваги різні акти жорстокого поводження, за яким були висунуті звинувачення, Суд постановив: «Дії певного характеру, які раніше на противагу «катуванню» класифікувалися як «нелюдське і принижуюче гідність поводження», у подальшому будуть класифікуватися інакше. Суд вважає, що зростаючі високі стандарти захисту прав і основних свобод людини відповідно і неминуче вимагають більшої твердості у визначенні порушень проти основних цінностей демократичного суспільства» [11].

У встановленні ступеня жорстокості Суд скористався підходом, який застосовувався у справі Ірландії проти Великої Британії, тобто спирався на те, що встановлення ступеня жорстокості залежить від усіх обставин розгляду справи. Такий підхід $є$ цілком правильним $з$ погляду потреби врахування реальної ситуації та відповідно ступеня фізичних та психічних страждань потерпілої особи.

До того ж, роблячи посилання на ст. 1 Конвенції
ООН проти катувань, Суд тим самим підкреслив, що застосування тортур переслідує собою певну мету. Саме елемент навмисності, як уже зазначалося вище, у рішенні у справі Греції визнаний визначальною характеристикою тортури, але у наступних справах розглядався як маргінальний.

Отже, Суд не зв'язаний будь попередніми рішеннями і зберігає за собою можливість переоцінки прецедентного права та розгляду дій, які раніше не вважалися катуванням [10].

\section{«Нелюдське поводження або покарання»}

Жорстоке поводження, яке не визнається катуванням СКПЛ чи ЄСПЛ з причини недостатнього рівня жорстокості, інтенсивності або цільової спрямованості, класифікується як нелюдське чи принижуюче гідність поводження. Оцінка мінімального рівня завжди має відносний характер у кожній конкретній справі і залежить від врахування ії фактичних обставин і іноді особливостей національного законодавства.

У справі Греції не тільки було розмежовано поняття катування від інших форм жорстокого поводження, але й визнано за необхідне провести розмежування між нелюдським і принижуючим гідність видами поводження на підставі ступеню жорстокості.

Комісія постановила, що нелюдське поводження $\epsilon$ «таким видом поводження, яким заподіюються сильні страждання, моральні або фізичні, які в даній ситуації не можуть бути виправдані» [2]. У справі Ірландії проти Великої Британії Комісія ще раз висловила думку про те, що «будь-яке визначення кожного $з$ положень ст. 3 Конвенції має спиратися на поняття «нелюдське поводження» [3].

Виходячи 3 наявної судової практики, можна припустити, що нелюдському поводженню відповідають дії, які «не порушили поріг жорстокості». На це поняття спираються і у визначенні поводження як такого, що принижує гідність, тобто такого поводження, яке було настільки жорстоким, щоб бути розціненим як нелюдське. Тут мова йде про аксіологічну категорію гідності, що незалежно від ступеня жорстокості сама вже є причиною для застосування захисту прав індивіда.

У справі «Ірландї̈ проти Великої Британії» (1977) [3] деякі із затриманих скаржилися, що співробітники силової структури били їх ногами і кулаками. Медичні свідоцтва підтвердили наявність у них синців і саден, завданих під час їх тримання під вартою. ЄСПЛ констатував, що побиття призвело до сильних страждань і фізичних травм, які часом були дуже серйозними; так, даний випадок підпадає під категорію нелюдського поводження.

У справі «Балох проти Угорщини» (2004) [12] у ході допиту один з офіцерів кілька разів бив заявника в обличчя і ліве вухо. Через два дні після свого звільнення заявник переніс операцію з відновлення барабанної перетинки. Суд постановив, що травма була досить серйозною, а отже, становила жорстоке поводження за ст. 3.

У справі "Гафен проти Німеччини» (2008) [13] під час допиту заявника йому погрожували застосуванням фізичного насильства, яке заподіяло б йому значний біль, з тим, щоб змусити його розкрити місцезнахо- 
дження хлопчика, якого він викрав. Суд зазначив, що таке поводження, застосоване до заявника заподіяло йому сильні душевні страждання, що й було проілюстровано тим фактом, що якщо раніше він неодноразово відмовлявся від дачі свідчень, то під час застосування загроз він зізнався, де сховав хлопчика. Тому Суд знайшов, що таке поводження прирівнюється до катувань. Однак, оскільки допит тривав лише 10 хвилин і проводився в атмосфері підвищеної напруги й емоцій внаслідок того, що поліцейські, абсолютно виснажені, під величезним тиском вважали, що в їх розпорядженні було тільки кілька годин, щоб врятувати життя хлопчика, Суд визначив, що заявник зазнав під час допиту зверненням, яке він розглядає як нелюдське в порушення ст. 3.

Аналізуючи вказане рішення, можна констатувати абсолютний характер заборони катувань та інших видів неналежних поводжень поширюється на всіх суб'єктів, навіть підозрюваних у важких злочинах із врахуванням фундаментальності права на життя, здоров'я та гідність. Крім того, ілюструється вплив суб'єктивних факторів справи, таких як тривалість допиту, психічний і фізичний стан поліцейських тощо.

\section{«Покарання"}

Практика Суду стосовно покарань незначна, оскільки у більшості справ, переданих до Суду, мова йде про поводження з особами, що позбавлені свободи.

Яскравим прикладом застосування статті 3 Конвенції у контексті покарання є справа «Чембер проти Pociï» (2008) [14]. Заявник під час проходження військової служби страждав від періодичних болів у колінах. Зокрема, з цієї причини заявник був звільнений від фізичної та стройової підготовки. Не зважаючи на це, в якості покарання за погане прибирання казарми, йому було наказано зробити 350 присідань в якості дисциплінарного покарання, через що він залишився інвалідом.

Суд зазначив, що суворість такого покарання неможна пояснити будь-якою дисциплінарної або військовою необхідністю, і постановив, що таке покарання було навмисно розраховане на заподіяння заявнику сильних фізичних страждань. Відповідно Суд знайшов, що заявник був підданий нелюдському виду покарання в порушення ст. 3 Конвенції.

\section{Щоводження або покарання, що принижує людську гідність"}

На відміну від нелюдського поводження, визначення поняття «поводження, щчо принижує гідність»є базовим у кваліфікації правопорушення за ст. 3 Конвенції. Тобто у визначенні чи порушено ст. 3 Конвенції принцип поваги до людської гідності $є$ ключовим фактором. Отримавши свідчення того, що цей принцип був порушений, Суд може постановити порушення ст. 3 Конвенції, навіть якщо порушником не було скоєно насильних дій.

Доволі часто Суд у своїх рішеннях робить висновок про те, що потерпіла особа піддавалася як нелюдському, так і такому, що принижує гідність поводженню, наприклад, у справах «Томасі проти Франції» (1992) [15], «Hulki Gunes v Turkey» (2003) [16], «Piвас проти Франціï» (2004) [17]. Однак у практиці Суду проводиться розмежування між цими двома видами неналежного поводження. Зустрічаються рішення, в котрих зазначається лише про посягання на людську гідність людини без жорстоко поводження, чи катування.

Наприклад, це справи, пов'язані із неналежними умовами тримання осіб, що позбавлені свободи, у місцях позбавлення волі, тимчасових ізоляторах, медичних, психіатричних установах. У справі «Пісрс проти Греціi» (2001) [18] встановлено, що умови утримання ув'язненого не відповідають умовам утримання особи, що вимагає спостереження психіатрів. Суд постановив, що хоча і не було доказів «Умисного образи чи приниження гідності заявника» [18], тим не менше, неможна виключити можливість, що порушення закону мало місце. Суд постановив, що бездіяльність влади свідчить про «відсутність поваги до заявника» [18], а отже, у даному випадку мало місце порушення ст. 3 .

Однією із останніх справ у розрізі ст. 3 Конвенції, а саме кваліфікація правопорушення як такого, що принижує гідність особи є «Емnур проти Румунії» (2021) [19]. Суд встановив порушення ст. 3 Конвенції на підставі того, що медична допомога, яка була надана контролюючим органом, не $є$ організованою допомогою з боку держави для забезпечення того, щоб заявник був утриманий в умовах, сумісних 3 дотриманням його людської гідності.

До цієї категорії справ можна віднести і ті, в яких Суд встановив процесуальні порушення у проведені особистого обшуку особи. У справі «Лорс проти $\mathbf{H i -}$ дерландів" (2003) [20] та справі «Ван Дер Вен проти Нідерландів»(2003) [21]. Засудженні піддавались особистому обшуку кожного тижня, тоді як Суд постановляє, що такі обшуки можуть проводитись із причин запобігання реальній небезпеці. В ілюстрованих випадках особисті обшуки проводились в додаток до інших мір безпеки. Так, Суд вважає, що такі регулярні обшуки були тими заходами, що принижували людську гідність.

Яскраво ілюструє порушення принципу поваги до людської гідності справа «Янков проти Болгарії» (2003) [22]. Заявнику, котрий тримався в ізоляторі 7 днів, насильно побрили голову. Крім того, не було доведено, що цей захід був проведений з гігієнічних причин. Суд постановив, що насильна зміна зовнішності людини є приниженням іiі гідності.

Отже, аналізуючи практику Суду, можна визначити неналежне поводження, що принижує гідність людини як поводження, що носить досить грубий характер. Такий підхід до розгляду поводження, що принижує гідність людини, застосовувався і був вдосконалений у розслідуванні у більшості тих справ, за якими висувалися звинувачення у застосуванні тілесних покарань. Особливий акцент треба поставити на грубому характері такого відношення і відповідно на істотності його фізичного та (або) психічного впливу на потерпілу особу.

Одним з найбільш яскравих прикладів вищевказаного судового підходу є справа «Тайрера проти Великої Британії» (1978) [6].

У справі висунуто звинувачення в тому, що згідно з судовим рішенням, п'ятнадцятирічного підлітка обвинуваченого у незаконному нападі, повинні були сікти різками.

Крім того, дана справа є однією із тих випадків 
застосування Судом терміну «покарання, щзо принижує гідність». Після того як було визначено, що ступінь жорстокості покарання не відповідає ступеню жорстокості катування або нелюдського поводження, Суд перейшов до розгляду питання, чи $є$ таке покарання таким поводженням, що принижує гідність.

У судовому рішенні зазначалося: «До ст. 3 відноситься те, що він безперечно був ображений не тільки винесеним вироком, а й застосованим до нього покаранням. 3 тим, щоб покарання було кваліфіковано як «принижує гідність» і суперечило ст. 3, образа або приниження має досягти певного рівня» [6].

До того ж Суд визначив деякі критерії для визначення ступеня нанесеної образи або приниження. Суд постановив, що визначення «є відносним: воно залежить від усіх обставин стосовно даної справи i, особливо, від характеру і змісту самого покарання, а також від манери і способу його виконання».

Отже, засуджена особа може стверджувати, що поводження принижує його гідність, тільки коли рівень приниження перевищує притаманний будь-якому покаранню. Згідно зі ст. 3, що принижує гідність, поводження і покарання має виражатися не стільки у винесеному вироку, скільки в тому, як цей вирок приводиться до виконання. Водночас досить того, що жертва відчуває себе приниженою у власних очах. Узагальнюючи під таким, що принижує гідність, поводженням, мається на увазі поведінка яка викликає у потерпілої особи почуття страху, тривоги, неповноцінності, що спричиняє приниження чи залякування, а також зниження психологічного чи фізичного опору такої особи. Також важливо зазначити , що такі факти як стать чи вік мають важливе значення для оцінювання діяння як такого, що принижує гідність.

\section{ВИСНОВКИ}

Абсолютний характер норми јus cogens ст. 3 Конвенції червоною ниткою пронизує всі рішення європейських судових установ. Нікого не може бути піддано катуванню або нелюдському чи такому, що принижує гідність, поводженню або покаранню - правило, яке має абсолютний характер. За роки діяльності ЄСПЛ та ЄКПЛ застосування цієї норми поширилось на правовідносини у різних сферах життя країн-учасниць Ради Свропи. Багата судова практика та динамічне тлумачення Судом положень Конвенції значно розширила розуміння ст. 3 Конвенції. На прикладах реальних кейсів Суд та Комісія, з огляду на індивідуальні обставини кожної справи, надавали визначення та юридичну кваліфікацію різним правопорушенням. На сьогодні існує низка критеріїв, за якими здійснюється оцінювання тих чи інших діянь. Частина 3 цих критеріїв має аксіологічний характер і цим сприяє уніфікації підходів до охоронюваних Конвенцією цінностей. Однак кожного разу Суд наголошує, що Конвенція з прав людини та основоположних свобод є живим інструментом у руках суддів, - визначаючи основний принцип поваги до людської гідності, вона регулює широке коло питань.

Так, у процесі діяльності Суду та Комісії, керуючись критерієм «мінімального рівня жорстокості» розмежовано поняття «катування», «нелюдське поводження або покарання» та «поводження або покарання, що принижує людську гідність». «Плаваюча» шкала оцінки кожного правопорушення надає певну свободу у дослідженні обставин справи та має на меті дотримання Судом принципу справедливості та неупередженості, а також, максимальної ефективності захисту фундаментальних прав людини.

На противагу європейському конвенційному регулюванню неналежного поводження, катування, нелюдського чи принижуючого гідність поводження та покарання, українське законодавство це питання регулює досить лаконічно. Ст. 127 Кримінального Кодексу України надає визначення лише катуванню, що по своїй суті збігається із визначенням Конвенції ООН проти катувань та позицією ССПЛ.

Однак, практика українських судів показує, що розмежування, подібного до того, яке надає ЄСПЛ, не здійснюється. 3 одного боку це є наслідком властивостей континентальної правової системи, де прецедент традиційно не є джерелом права. Вбачається, доцільним модернізація українського кримінального законодавства 3 проведення рецепції позиції ЄСПЛ із розмежування вказаних понять. Існує практична потреба у розробленні змін до Кримінального кодексу України, які доповнюватимуть кодекс статтями, що регулюватимуть й інші види неналежного поводження. Це сприятиме кращому реагуванню національної правової системи на ці системні правопорушення, надасть можливість судам надійніше забезпечувати захист прав осіб, що гарантуються Конвенцією. Належна кримінально-правова охорона права особи на гідність створює належні основи для захисту фундаментальних прав індивіда.

Орієнтація законодавця на подібну практику ЄСПЛ $\epsilon$ ключовою у процесі формування людиноцентристської правої ідеології в Україні та модернізації національного механізму захисту прав людини.

\section{Список використаних джерел}

1. Конвенція про захист прав людини і основоположних свобод від 04.11.1950. URL: https://zakon.rada.gov.ua/laws/show/995_004\#Text

2. Council of Europe, European Commission of Human Rights. The Greek case (Application No. 3321/67 - Denmark v . Greece, Application No. 3322/67 - Norway v. Greece, Application No. 3323/67 - Sweden v . Greece, Application No. $3344 / 67$ - Netherlands v. Greece), Report of the subcommission. Strasbourg, 1969. $177 \mathrm{p}$.

3. Case of Ireland v. The United Kingdom (Application no. 5310/71): Judgment European Court of Human Rights, January 18, $1978 . \quad$ URL: https://hudoc.echr.coe.int/eng\#\{\%22itemid\%22:[\%22001$57506 \% 22]\}$

4. Декларація про захист усіх осіб від катувань та інших жорстоких, нелюдських або таких, що принижують гідність, видів поводження і покарання. Резолюція ООН від 09.12.1975.

URL: https://zakon.rada.gov.ua/laws/show/995_084\#Text

5. Конвенція проти катувань та інших жорстоких, нелюдських або таких, що принижують гідність, видів поводження i покарання від 10.12.1984. URL: https://zakon.rada.gov.ua/laws/show/995_085\#Text

6. Case of Tyrer v. The United Kingdom (Application no. 5856/72): Judgment European Court of Human Rights, April 25, $1978 . \quad$ URL: https://hudoc.echr.coe.int/fre\# \{\%22itemid\%22:[\%22001$57587 \% 22]\}$ 
7. Case of Aksoy v. Turkey(Application no. 21987/93): Judgment European Court of Human Rights, December 18, 1996.

URL: https://hudoc.echr.coe.int/eng\# $\{\% 22$ fulltext $\% 22:[\% 22$ Aksoy $\% 2$ 0v.\%20Turkey\%22],\%22documentcollectionid2\%22:[\%22GRA NDCHAMBER\%22,\%22CHAMBER\%22],\%22itemid\%22:[\% 22001-58003\%22]\}

8. Case of Salman v Turkey (Application no. 21986/93): Judgment European Court of Human Rights, June 27, 2000. URL: https://hudoc.echr.coe.int/tur\#\{\%22itemid\%22:[\%22001$58735 \% 22]\}$

9. Dikme v. Turkey (Application no. 20869/92): Judgment European Court of Human Rights, July 11, 2000. URL: https://hudoc.echr.coe.int/fre\#\{\%22itemid\%22:[\%22002$5912 \% 22]\}$

10. Case of Aydin v. Turkey (57/1996/676/866): Judgment European Court of Human Rights, September 25, 1997. URL: https://hudoc.echr.coe.int/fre\#\{\%22itemid\%22:[\%22001$58371 \% 22]\}$

11. Рішення у справі "Селмуні проти Франції" від 28.07.1999. URL: https://zakon.rada.gov.ua/laws/show/ $980 \_374 \#$ Text

12. Case of Balogh v. Hungary (Application no. 47940/99): Judgment European Court of Human Rights, July 20, 2004. URL:

https://hudoc.echr.coe.int/eng\# $\{\% 22$ fulltext $\% 22:[\% 22$ Case $\% 20$ of $\% 20$ Balogh\%20v.\%20Hungary\%22],\%22documentcollection id2\%22:[\%22GRANDCHAMBER\%22,\%22CHAMBER\%22], $\% 22$ itemid\%22:[\%22001-61931\%22]\}

13. Case of Gäfgen v. Germany. (Application no. 22978/05): Judgment European Court of Human Rights, June 1, 2010.

URL:

https://hudoc.echr.coe.int/eng\# $\{\% 22$ fulltext $\% 22:[\% 22$ Case $\% 20$ of $\% 20 \mathrm{G} \% \mathrm{C} 3 \%$ A4fgen\%20v.\%20Germany\%22],\%22document collectionid2\%22:[\%22GRANDCHAMBER\%22,\%22CHAMB ER\%22],\%22itemid\%22:[\%22001-99015\%22]\}

14. Case of Chember v. Russia (Application no. 7188/03): Judgment European Court of Human Rights, July 3, 2008. URL: https://hudoc.echr.coe.int/tur\#\{\%22fulltext $\% 22:[\% 22$ Chember \%20v.\%20Russia\%22],\%22documentcollectionid2\%22:[\%22G RANDCHAMBER\%22,\%22CHAMBER\%22],\%22itemid\%22: [\%22001-87354\%22]\}

15. Tomasi v France (Application No. 12850/87): Judgment European Court of Human Rights, August 27, 1992. URL: https://hudoc.echr.coe.int/fre\#\{\%22itemid\%22:[\%22001$57796 \% 22]\}$

16. Hulki Gunes v Turkey (Application No. 28490/95): Judgment European Court of Human Rights, June 19, 2003. URL: https://hudoc.echr.coe.int/fre\#\{\%22fulltext $\% 22:[\% 22$ Hulki\%20 Gunes\%20v\%20Turkey\%22],\%22documentcollectionid2\%22:[ $\% 22$ GRANDCHAMBER $\% 22, \% 22$ CHAMBER $\% 22], \% 22$ itemi d\%22:[\%22001-61169\%22]\}

17. Affaire Rivas C. France (Requete no 59584/00) Arret La Cour europeenne des Droits de l'Homme, 1er Avril 2004. URL: https://hudoc.echr.coe.int/eng\#\{\%22itemid\%22:[\%22001$66247 \% 22]\}$

18. Case of Peers v. Greece (Application no. 28524/95): Judgment European Court of Human Rights, April 19, 2001. URL: https://hudoc.echr.coe.int/tur\#\{\%22itemid\%22:[\%22001$59413 \% 22]$ \}

19. Case of Epure v. Romania (Application no. 73731/17): Judgment European Court of Human Rights, May 11, 2021. URL: https://hudoc.echr.coe.int/eng\# $\{\% 22$ documentcollectionid $2 \% 22$ :[\%22GRANDCHAMBER $\% 22, \% 22$ CHAMBER $\% 22], \% 22$ ite $\operatorname{mid} \% 22:[\% 22001-210083 \% 22]\}$

20. Case of Lorse and others v. The Netherlands (Application no. 52750/99): Judgment European Court of Human Rights, February 4, 2003. URL https://hudoc.echr.coe.int/eng\# \{\%22fulltext $\% 22:[\% 22$ lorse $\% 20$ v\%20netherlands\%22],\%22documentcollectionid2\%22:[\%22G
RANDCHAMBER\%22,\%22CHAMBER\%22],\%22itemid\%22: [\%22001-60916\%22]\}

21. Case of Van Der Ven v. The Netherlands (Application no. 50901/99): Judgment European Court of Human Rights, February 4, 2003. URL: https://hudoc.echr.coe.int/eng\# $\{\% 22$ fulltext $\% 22:[\% 22 \mathrm{van} \% 20 \mathrm{~d}$ er\%20ven $\% 20 \mathrm{v} \% 20$ netherlands $\% 22], \% 22$ documentcollectionid 2\%22:[\%22GRANDCHAMBER\%22,\%22CHAMBER\%22],\% 22itemid\%22:[\%22001-60915\%22]\}

22. Case of Yankov v. Bulgaria (Application no. 39084/97): Judgment European Court of Human Rights, December 11, 2003.

URL: https://hudoc.echr.coe.int/eng\# $\{\% 22$ fulltext $\% 22:[\% 22$ yankov\% 20v\%20bulgaria\%22],\%22documentcollectionid $\% 22:[\% 22 \mathrm{GR}$ ANDCHAMBER\%22,\%22CHAMBER\%22],\%22itemid\%22:[ $\% 22001-61539 \% 22]\}$

23. Case of Tyrer v. The United Kingdom (Application no. 5856/72): Judgment European Court of Human Rights, 25 April 1978.

URL:

https://hudoc.echr.coe.int/fre\#\{\%22itemid\%22:[\%22001$57587 \% 22]\}$

\section{$\underline{\text { References }}$}

1. Convention for the Protection of Human Rights and Fundamental Freedoms of November 4, 1950. URL: https://zakon.rada.gov.ua/laws/show/995_004\#Text (in Ukrainian)

2. Council of Europe, European Commission of Human Rights. The Greek case (Application No. 3321/67 - Denmark v . Greece, Application No. 3322/67 - Norway v. Greece, Application No. 3323/67 - Sweden v . Greece, Application No. $3344 / 67$ - Netherlands v. Greece), Report of the subcommission. Strasbourg, 1969. $177 \mathrm{p}$.

3. Case of Ireland v. The United Kingdom (Application no. 5310/71): Judgment European Court of Human Rights, 18 January 1978. URL: https://hudoc.echr.coe.int/ eng\#\{\%22itemid\%22:[\%22001-57506\%22]\}

4. Declaration on the Protection of All Persons from Being Subjected to Torture and Other Cruel, Inhuman or Degrading Treatment or Punishment Adopted by General Assembly resolution 3452 (XXX) of December 9, 1975. URL: https://zakon.rada.gov.ua/laws/show/995_084\#Text (in Ukrainian)

5. Convention against Torture and Other Cruel, Inhuman or Degrading Treatment or Punishment Adopted and opened for signature, ratification and accession by General Assembly resolution 39/46 of 10 December 1984 entry into force June 26, 1987, in accordance with article 27 (1). URL: https://zakon.rada.gov.ua/laws/show/995_085\#Text (in Ukrainian)

6. Case of Tyrer v. The United Kingdom (Application no. 5856/72): Judgment European Court of Human Rights, April 25, 1978. URL: https://hudoc.echr.coe.int/ fre\# $\{\% 22$ itemid $\% 22:[\% 22001-57587 \% 22]\}$

7. Case of Aksoy v. Turkey(Application no. 21987/93): Judgment European Court of Human Rights, December 18, 1996.

URL: https://hudoc.echr.coe.int/eng\# $\{\% 22$ fulltext $\% 22:[\% 22$ Aksoy $\% 2$ 0v.\%20Turkey\%22],\%22documentcollectionid2\%22:[\%22GRA NDCHAMBER\%22,\%22CHAMBER\%22],\%22itemid\%22:[\% 22001-58003\%22]\}

8. Case of Salman v Turkey (Application no. 21986/93): Judgment European Court of Human Rights, June 27, 2000. URL: https://hudoc.echr.coe.int/tur\#\{\%22itemid\%22:[\%22001$58735 \% 22]\}$

9. Dikme v. Turkey (Application no. 20869/92): Judgment European Court of Human Rights, July 11, 2000. URL: https://hudoc.echr.coe.int/fre\# \{\%22itemid\%22:[\%22002$5912 \% 22]\}$

10. Case of Aydin v. Turkey (57/1996/676/866): Judgment European Court of Human Rights, September 25, 1997. URL: https://hudoc.echr.coe.int/fre\# \{\%22itemid\%22:[\%22001$58371 \% 22]\}$ 
11. Case of Selmoni v. France of July 28, 1999. URL: https://zakon.rada.gov.ua/laws/show/980 374\#Text (in Ukrainian)

12. Case of Balogh v. Hungary (Application no. 47940/99): Judgment European Court of Human Rights, July 20, 2004. URL:

https://hudoc.echr.coe.int/eng\# $\{\% 22$ fulltext $\% 22:[\% 22$ Case $\% 20$ of $\% 20$ Balogh $\% 20$ v.\%20Hungary $\% 22], \% 22$ documentcollection id2\%22:[\%22GRANDCHAMBER \%22,\%22CHAMBER\%22], \%22itemid\%22:[\%22001-61931\%22]\}

13. Case of Gafgen v. Germany. (Application no. 22978/05): Judgment European Court of Human Rights, June 1, 2010.

URL: https://hudoc.echr.coe.int/eng\# $\{\% 22$ fulltext $\% 22:[\% 22$ Case $\% 20$ of $\% 20$ G\%C3\%A4fgen\%20v.\%20Germany $\% 22], \% 22$ document collectionid $\% 22:[\% 22$ GRANDCHAMBER $\% 22, \% 22$ CHAMB ER\%22],\%22itemid\%22:[\%22001-99015\%22]\}

14. Case of Chember v. Russia (Application no. 7188/03): Judgment European Court of Human Rights, July 3, 2008. URL: https://hudoc.echr.coe.int/tur\#\{\%22fulltext $\% 22:[\% 22$ Chember \%20v.\%20Russia\%22],\%22documentcollectionid2\%22:[\%22G RANDCHAMBER $\% 22, \% 22$ CHAMBER $\% 22], \% 22$ itemid $\% 22$ : [\%22001-87354\%22]\}

15. Tomasi v France (Application No. 12850/87): Judgment European Court of Human Rights, August 27, 1992. URL: https://hudoc.echr.coe.int/fre\# \{\%22itemid\%22:[\%22001$57796 \% 22]$ \}

16. Hulki Gunes v Turkey (Application No. 28490/95): Judgment European Court of Human Rights, June 19, 2003. URL: https://hudoc.echr.coe.int/fre\# $\{\% 22$ fulltext $\% 22:[\% 22 H u l k i \% 20$ Gunes\%20v\%20Turkey\%22],\%22documentcollectionid2\%22:[ \%22GRANDCHAMBER\%22,\%22CHAMBER\%22],\%22itemi d\%22:[\%22001-61169\%22]\}

17. Affaire Rivas C. France (Requete no 59584/00) Arret La Cour europeenne des Droits de l'Homme, 1er Avril 2004. URL: https://hudoc.echr.coe.int/eng\#\{\%22itemid\%22:[\%22001$66247 \% 22]\}$
18. Case of Peers v. Greece (Application no. 28524/95): Judgment European Court of Human Rights, April 19, 2001. URL: https://hudoc.echr.coe.int/tur\#\{\%22itemid\%22:[\%22001$59413 \% 22]\}$

19. Case of Epure v. Romania (Application no. 73731/17): Judgment European Court of Human Rights, May 11, 2021. URL: https://hudoc.echr.coe.int/eng\# \{\%22documentcollectionid $2 \% 22$ :[\%22GRANDCHAMBER\%22,\%22CHAMBER\%22],\%22ite mid\%22:[\%22001-210083\%22]\}

20. Case of Lorse and others v. The Netherlands (Application no. 52750/99): Judgment European Court of Human Rights, February 4, 2003. URL https://hudoc.echr.coe.int/eng\# \{\%22fulltext $\% 22:[\% 22$ lorse $\% 20$ v\%20netherlands\%22],\%22documentcollectionid2\%22:[\%22G RANDCHAMBER $\% 22, \% 22$ CHAMBER $\% 22], \% 22$ itemid $\% 22$ : [\%22001-60916\%22]\}

21. Case of Van Der Ven v. The Netherlands (Application no. 50901/99): Judgment European Court of Human Rights, February 4, 2003. URL: https://hudoc.echr.coe.int/eng\# $\{\% 22$ fulltext $\% 22:[\% 22 \mathrm{van} \% 20 \mathrm{~d}$ er\%20ven $\% 20 \mathrm{v} \% 20$ netherlands $\% 22], \% 22$ documentcollectionid 2\%22:[\%22GRANDCHAMBER\%22,\%22CHAMBER $\% 22$ ], $\%$ 22itemid\%22:[\%22001-60915\%22]\}

22. Case of Yankov v. Bulgaria (Application no. 39084/97): Judgment European Court of Human Rights, December 11, 2003.

URL: https://hudoc.echr.coe.int/eng\#\{\%22fulltext $\% 22:[\% 22$ yankov\% 20v\%20bulgaria $\% 22], \% 22$ documentcollectionid2\%22:[\%22GR ANDCHAMBER\%22,\%22CHAMBER\%22],\%22itemid\%22:[ $\% 22001-61539 \% 22]\}$

23. Case of Tyrer v. The United Kingdom (Application no. 5856/72): Judgment European Court of Human Rights, 25 April 1978.

URL: https://hudoc.echr.coe.int/fre\#\{\%22itemid\%22:[\%22001$57587 \% 22]\}$ 